\title{
COORDINATING FLOWS OF ORGANISATIONAL KNOWLEDGE: THE ROLE OF THE CORPORATE UNIVERSITY
}

\author{
V. KONOVALENKO SLETTLI \\ Inland Norway University of Applied Sciences, Norway ${ }^{\mathrm{a}}$ \\ K. GRØNHAUG \\ Norwegian School of Economics, Norway ${ }^{\mathrm{b}}$
}

This paper seeks to advance the understanding of the corporate university phenomenon by addressing the role that a corporate university plays in coordinating the flows of organisational knowledge. Drawing on the longitudinal in-depth case study of Severstal Corporate University, we illustrate how a corporate university contributes to dynamic knowledge management in the company by serving as a coordinator of its knowledge flows. The study provides evidence of how a corporate university - by performing three different knowledge-coordinating roles operates as a corporate function to support evolving business strategies during different periods of organisational development. The findings suggest the following roles of a corporate university are related to the coordination of knowledge flows: knowledge-harmonising, knowledge-disseminating, and knowledge-centralising. As a result of the study, a corporate university appears as a dynamic concept with development stages that can be explained from a teleological rather than life cycle perspective. That is, a corporate university's development is driven by its changing purpose and goals that are constructed and reconstructed according to the evolving knowledge needs of its parent company.

Keywords: corporate university, knowledge flows, coordination, strategic development, case study.

JEL: D83, M12, 121.

The role of knowledge for organisational well-being is difficult to underestimate. Unique organisational knowledge embedded in individuals, technologies, processes, and relations is argued to serve as the key to value-creation [Teece, 2000] and sustainable

\footnotetext{
a Address: Terningen Arena, Hamarvegen 112, Inland Norway University of Applied Sciences, 2411 Elverum, Norway.

b Address: Helleveien 30, Norwegian School of Economics, 5045, Bergen, Norway.

(C) V. Konovalenko Slettli, K. Grønhaug, 2017
}

DOI: $10.21638 / 11701 /$ spbu18.2017.103 
competitive advantage [Barney, 1991]. The need to manage organisational knowledge in a way that would support strategic vision and initiatives of the company led to the emergence and quick spread of the corporate university phenomenon [Rhéaume, Gardoni, 2015]. As a result, corporate universities (CUs) can now be found in various industries, geographical contexts, organisational forms, and financial models.

The concept of CUs (which is sometimes replaced by "corporate academies" or "institutes") implies a wide range of knowledge-focused activities aimed at facilitating knowledge sharing, organisational learning and human resource development, which are connected to the overall organisational strategic objectives (e.g., [Holland, Pyman, 2006; Allen, 2010; Antonelli, Cappiello, Pedrini, 2013; Rhéaume, Gardoni, 2016]).

Even though it is a relatively new phenomenon, CUs have been extensively described in the literature in regards to their organisational profile, including governance and leadership structure, stages of development, delivery of learning function with a focus on curriculum and evaluation of learning results, source of financing and use of IKT, and partnership relations (e.g., [Abel, Li, 2012; Alagaraja, Li, 2014]). An extensive study of 210 North American CUs addressed the prominent process of $\mathrm{CU}$ operations, among which the following were named: use of technology to support learning, alignment of corporate goals with the execution of the CU's learning and development strategies, and developing skills to support business needs [Abel, Li, 2012]. In Russia, the context of corporate education has experienced rapid development during the last twenty years, and a large number of companies chose to establish corporate universities to facilitate human resources and knowledge management practices (see for example, [Latukha, 2010; Gorshkov, Kliucharev, 2013; Dixon, Day, Brewster, 2014; Ardichvili, Zavyalova, 2015; Latukha, 2015]).
However, it seems previous studies oversaw an important function of CUs related to the coordination of flows of organisational knowledge. This view of the CU corresponds with the conceptual model of [da Silva, Agustí-Cullel, 2003, p. 54] who suggest that certain actors (who may be represented by individuals, software tools, organisational units, or whole companies) should perform the task of being "knowledge coordinators". In line with them, [Nielsen, Michailova, 2007, p. 319] suggest that in the arrangement of knowledge management systems it is often company headquarters that serves as the "knowledge hub/ broker" and the "coordinator of knowledge flows".

In this paper, we advance the understanding of the CU by proposing a new perspective on the subject matter and presenting the CU as a coordinator of corporate knowledge flows. The question of interest posed within this paper: How does a CU function to coordinate flows of organisational knowledge in the context of a multinational company (MNC)? Often, the context of an MNC is characterised by a complex organisational structure with a multilevel system of decision-making, feedback and control, broad geographical dispersion of business units, employees, and functions, various local cultures and language differences. These characteristics may provide a big challenge for a corporate university's "knowledge coordination" function.

To answer the main research question, we start by elaborating a theoretical framework for explaining the coordination of knowledge flows performed by a CU. Next, we provide the research methodology of the study and introduce the case organisation Severstal Corporate University. The next sections present our empirical findings, followed by a discussion of these. Finally, the last section highlights implications for practice and offers suggestions for further research. 


\section{Corporate university and the coordination of knowledge flows}

\section{Knowledge flows}

The scholarly literature suggests a number of varying approaches to defining and characterising knowledge flows. [Gupta, Govindarajan, 1991, p. 773], for instance, define knowledge flows as the "transfer of either expertise (e.g., skills and capabilities) or external market data of strategic value". They suggest that expertise can refer to input, throughput, and output business processes and be realised in procurement skills, knowledge of design, or distribution expertise. [Szulanski, 1996] views knowledge flows as a transfer of business practices, and [Ghoshal, Korine, Szulanski, 1994] view them as communication frequencies. [Schulz, 2003, p. 444] understands knowledge flows as "aggregate volume of knowhow and information transmitted per unit of time". Review of the literature addressing flows of knowledge in MNCs (see [Michailova, Mustaffa, 2012]) suggests that knowledge flows possess the following characteristics.

First, knowledge flows can be regarded in terms of type of knowledge transferred [Michailova, Mustaffa, 2012]. Thus, some scholars employ an "all-inclusive" notion of organisational knowledge while others concentrate on flows of technological (e.g., [Malik, 2004]) or marketing knowledge (e.g., [Holm, Sharma, 2006]). Yet again, others examine knowledge flows related to organisational practices (e.g., [Kostova, Roth, 2002]), learning systems (e.g., [Hong, Easterby-Smith, Snell, 2006]), and human resource practices [Sparkes, Miyake, 2000].

Second, transferring or transmitting this knowledge points to a certain directionality (e.g., [Michailova, Mustaffa, 2012]). This means, that knowledge flow, as a process, involves a sender and a receiver and can be considered in terms of vertical or horizontal flows, as well as inflow and outflow (e.g., [Schulz, 2001; 2003]).
Third, as can be seen from the definitions above, knowledge flows involve specific content. This content can be related to professional expertise in a particular area, relevant market information [Gupta, Govindarajan, 1991], business practices [Szulanski, 1996], etc.

Finally, knowledge flows point to various learning processes that involve different modes of cognition and interaction rooted in experience, experimentation, or communication [Garud, 1997]. In summary, for operationalisation purposes, we can use the following characteristics of knowledge flows: type of knowledge transferred, directionality, and knowledge content.

\section{Corporate university as a "coordinator" of knowledge flows}

In order to avoid the loss of organisational knowledge, scholars have recognised the need to coordinate knowledge flows across "a variety of units, teams and communities" [Kotlarsky, van Fenema, Willcocks, 2008, p. 99] and between organisational units "separated through time, space, culture and language" [Ambos, Ambos, 2009]. Due to the fact that different business units may possess different types of knowledge and competence, the way these units are coordinated in the company setting may affect the pattern of intra-organisational knowledge transfer [Tsai, 2002].

Coordination of knowledge flows can be understood as the "process of interconnecting individuals, organisational tasks and functions by the power exercised in work relations based on established order of rules in order to reach organisational goals related to enhancing organisational knowledge and learning" [Konovalenko Slettli, Grønhaug, 2016, p.58]. It is argued that coordination of knowledge flows can be facilitated by, but not reduced to, the mechanisms of organisational structure and disclosure/reporting of knowledge-related activity [Konovalenko Slettli, Grønhaug, 2016, p. 158]. 
Table 1

Theoretical framework for studying corporate university as coordinator of knowledge flows in the MNC context

\begin{tabular}{l|l}
\hline \multicolumn{1}{c|}{\begin{tabular}{c}
\multicolumn{1}{c}{\begin{tabular}{c}
\multicolumn{1}{c}{ of knoracteristics of CU as coordinator } \\
Type of knowledge [Michailova, Mustaffa,
\end{tabular}} \\
2012]
\end{tabular}} & $\begin{array}{l}\text { What are the specific knowledge, expertise, and competenc- } \\
\text { es to be transferred? }\end{array}$ \\
\hline $\begin{array}{l}\text { Knowledge-related efforts [Kotlarsky, } \\
\text { van Fenema, Willcocks, 2008] }\end{array}$ & $\begin{array}{l}\text { What are the specific knowledge-related tasks and efforts } \\
\text { performed by the CU while serving as coordinator of knowl- } \\
\text { edge flows? }\end{array}$ \\
\hline $\begin{array}{l}\text { Directionality [Michailova, Mustaffa, } \\
2012 \text { ] }\end{array}$ & $\begin{array}{l}\text { How are the knowledge flows directed? Who are the senders } \\
\text { and recipients? }\end{array}$ \\
\hline "Order" to be achieved [Kotlarsky, van & $\begin{array}{l}\text { What is the desired outcome of knowledge-focused activi- } \\
\text { ties? }\end{array}$ \\
\hline Fenema, Willcocks, 2008] & What is the period/phase of corporate development? \\
\hline
\end{tabular}

A number of studies seek to understand how knowledge is coordinated in MNCs. For example, [Kotlarsky, van Fenema, Willcocks, 2008, p. 96] define coordination of knowledge flows as "a problem of sharing, integrating, creating, transforming, and transferring knowledge". For them "coordination is less about scheduling pre-defined tasks and more about interrelating the efforts of knowledgeable professionals in a concerted manner, i. e., to achieve order" [Kotlarsky, van Fenema, Willcocks, 2008, p. 99]. [da Silva, Agustí-Cullel, 2003, p. 51] perceive "knowledge coordination" as "design and use of organized and purposeful strategies to control knowledge distribution and dissemination across organizations".

Summarising the literature review presented in this section, and pertinent to this study, we are highlighting elements that characterise a corporate university as a coordinator of knowledge flows. The first element - type of knowledge transferred reflects the characteristics of knowledge flows. The second element refers to the knowledge-related efforts of a corporate university, or its units [Kotlarsky, van Fenema, Willcocks, 2008]. The third element directionality - points to the direction of knowledge flows. The fourth element is the "order" to be achieved [Kotlarsky, van Fe- nema, Willcocks, 2008], which can be understood as the desired outcome of the knowledge-focused activities. Finally, the fifth element is timing [da Silva, Agustí-Cullel, 2003], which is understood as characteristics of a particular period in the strategic development of the parent company. These elements are summarised in the theoretical framework in table 1.

\section{Research methodology}

The field research took place at Severstal Corporate University (SCU) ${ }^{1}$ during the period from 2007-2010. SCU was owned by the Severstal Group - an international, vertically integrated metals and mining company with its headquarters and major production centres located in Russia. In 2007, Severstal Company was reported as the 15th largest international and second largest domestic steel producer with revenues of US\$ 15245 million, representing therefore an important business company for Russia and for the world steel industry. In 2010, Severstal encompassed three principal

1 Severstal Corporate University was in operation from August 2001 up till March 2010. Afterwards it was transformed into a different entity a "Directorate of human resource recruitment and development". 
divisions that employ more than 90000 people and had operations that stretch across Europe and North America.

SCU, located in the city of Cherepovets, Russia, was established as a centre for education, information, methodology, and consulting for business units within the Severstal Group, and the number of enterprises who made use of the SCU's services counted more than 50. SCU claimed to have four main functions: knowledge management, consulting, research, and training and HR development. SCU's projects and programs implementation was provided on campus or via elearning systems that employed the intranet and the Internet. The SCU IT system provides access to corporate information resources to the Severstal Group enterprises located both in Russia and overseas.

In correspondence with the Law on Education, a Supervisory Board officially and formally governed SCU's activity. The Board consisted of 10 members, and included Severstal top managers and the directors of the largest divisions. In particular, Severstal CEO, Severstal deputy CEOs in various areas, and the SCU Director were involved in the SCU Supervisory Board. The Board was a superior governing body charged with a function of approving the major areas of SCU work and projects to be undertaken, as well approving the SCU's budget and accounts. The Board defined SCU's long-term and current perspectives at strategic levels, and its decisions were obligatory.

SCU employed a pool of experts and managers with work experience from the Severstal Group. The full-time staff counted about 80 people in 2008, most of whom possessed a scientific postgraduate degree, an MBA, or two higher education degrees. In cases where there was a need for experts in some specific areas of teaching or consultancy, SCU employed people on a short-term contractual basis.

The study employs a descriptive and exploratory design. The study was thought to especially benefit from using interviews as the primary data sources. The methodological approach in this study combined primary and secondary data sources. Empirical data has been gathered through qualitative interviewing, participation in work meetings in the case organisation, company records, mass media publications, websites, and other publicly available data. Triangulation method, which refers to the combination of methodologies in the study of the same phenomenon, was applied.

The bulk of interview data was gathered in three steps - spring 2007, spring 2008, and winter 2010. In total, 12 interviews (group and individual) lasting between 0,5 and 1,5 hours were undertaken; they were tape-recorded and/or followed with written notes. Ten people participated in the interviews, and four of them were interviewed twice. The scope of interviewees encompasses people representing various SCU units/functional areas and included the SCU director, six heads of SCU departments, two project coordinators, and one program leader. The interview questions were semistructured, open-ended, and invited open and emergent narration about SCU operations and practices. The first set of interviews allowed the researcher to gain preliminary understanding of the phenomenon in question. After transcription and analysis of the first-round interviews, a set of clarifying questions has been formulated in order to gain a deeper understanding of knowledge management practices in the context of a CU. Those questions were posed and discussed during the second-round interviews.

Besides interviews, some observations were made on location, for example, at the work group meetings and project discussions. The understanding of how the SCU served as coordinator of knowledge flows obtained from the primary sources was enhanced by the study of internal documents and materials, such as feedback questionnaires, knowledge management policies, 
reports on research projects, corporate databases, training program leaflets, and issues of corporate magazine.

\section{The case of Severstal Corporate University}

This section discusses the operation of SCU in the context of its parent company Severstal. The study revealed that at as the strategic aspirations of Severstal evolved, so did its knowledge needs. The SCU's mission was to assist its parent company in satisfying these knowledge needs via performing a variety of knowledge-related tasks and activities. The following subsections highlight three specific stages in the history of Severstal's strategic development as well as how the company's particular knowledge needs were reflected in SCU's operation at each stage.

\section{The carrier of best practices}

The first regarded period of Severstal's strategic development, covering 2001-2002, can be defined as the initial phase of business and the accumulation of assets in the domestic market. Dynamic expansion of the company and diversification into various branches defined the new corporate knowledge needs:

The Severstal Group started being formed around the Cherepovets steel plant... and a multi-branch diversified Group of enterprises evolved (The Severstal Group). Therefore the need for a tool appeared, which could quickly transfer effective managerial technologies and help in moulding a common business language and essential improvement of middle and top management (SCU Director).

The SCU's primary task was to provide integration between the business units of the newly established group and transfer/circulate "best practices" among them:

Severstal Company had its key competencies in managing distressed assets (assets in a bad state but with a good potential), that is, improving their state to "excellent". This was possible due to obtained managerial experience, knowledge, and efficient technologies, the so-called "best practices" which were transmitted from enterprise to enterprise within the group. At this time, Severstal Company adopted a diversification strategy, and the group entered into other branches than just steel: mining, automobile, forestry, heavy machinery, etc. This is why the "corporate university" was created - as a certain tool making it possible to transmit these best practices quickly enough, while using various methods of knowledge sharing: both traditional training, internal consulting, and development of the knowledge management system. (SCU Director)

The great diversity of the Severstal enterprises served as the major challenge for the whole Group. Some of the enterprises focused on the extraction of raw materials, whereas others were engaged in production activity. The domestic business units were geographically scattered over different parts of Russia. Before the Group was formed, each business unit had been an independent enterprise with its own business traditions, approaches, culture, and way of organising. Therefore, the enterprises of the Severstal Group - with their specific traditions, values, symbols, and cultural elements were in need of having something in common that would signify their belonging to the Group.

In order to achieve a certain degree of commonality among enterprises, SCU undertook several initiatives. First, it elaborated a set of corporate standards. They specified the norms and rules common to all the business units and were meant to provide unity in the methodological, organisational, and technical approaches with regard to management within the Group. The system of corporate standards was supposed to highlight common and mainstream management principles and to regulate in- 
ternal relations in the Severstal Group. The standards addressed a variety of issues, such as the organisation of financial flows, the allocation of functional responsibilities, the rules for decision-making, issues of corporate self-organising, the relations between management and shareholders, company management and the business units, etc. [The Synergy, 2004].

Another SCU initiative was the launch of the corporate magazine The Synergy. Before the SCU's own website appeared, [The Synergy, 2004-2008] was the only source of information about the SCU's activities and initiatives, major corporate events and projects, achievements, and results. The target audience of the magazine were the managers of the Severstal enterprises, and the first circulation numbered approximately 200 issues, which increased over time.

The third initiative related to the transferring of best practices was the so-called corporate studies. The studies were perceived as a crucial tool for investigating employees' perceptions, which could assist in evaluating top management's actions and the changes introduced into the practices of the business units. In this sense, corporate studies revealed "signs of business environment" related to the adoption of new management practices and business technologies (or "best practices") at the group enterprises.

Consulting activity performed by the SCU's own Consultancy Centre was seen as another important effort toward the unification of the management practices in the Group. The purposes of consulting included the development of a common business culture and integration across the Severstal enterprises, as well as spreading and sharing "best practices" among Severstal business units.

In summary, during the regarded period, SCU was tasked with facilitating a certain degree of commonality in the business practices of the dissimilar enterprises that made up the Severstal Group. Obtaining this commonality involved several major initiatives.
First, SCU focused on "harmonising" business processes across Severstal business units via the elaboration and implementation of corporate standards. Second, it facilitated the transfer of "best practices" among the Severstal enterprises via consulting efforts. Finally, SCU sought to ensure the effect of change implementation via performing corporate studies.

\section{The Service Centre}

The second regarded period, 2003-2005, is characterised by Severstal's further growth and the diversification of the business due to active acquisitions and an increase in production. The intention of the company was to participate in the global consolidation of the steel industry and to become one of the top companies in the global steel market. Simultaneously, Severstal continued to emphasise its long-term strategic focus on domestic markets. With these premises, the company adopted the strategy of decentralisation, granting divisions essential freedoms in relation to decision-making. In the light of these strategic aspirations, SCU obtained a new set of knowledge-related tasks:

During that period it was assumed that the company would be characterized by a high degree of decentralization, with great divisional autonomy, with a very divergent corporate culture, different business practices, and own business strategies... At this period characterized by strong decentralization, a minimal amount of central corporate initiatives existed. Severstal Corporate University was to a great extent performing the role of a "service centre". Based mainly on the tasks given by different divisions and enterprises of the Group, and by the Corporate Centre, we elaborated certain programmes, projects, studies, etc., and then realized them for our clients. (SCU Director)

Thus, the SCU role shifted from being a "carrier of best practices" to a centre performing a variety of services for the 
Severstal enterprises. Acting as a "service centre" implied increasing the scope and scale of SCU activities as well as introducing new ones. To illustrate this shift, the existing activities were developed further and some new ones were launched.

During this stage, the SCU essentially developed the portfolio of its training programmes. Originally, it provided two types of training programmes - "standard corporate" and "tailor-made". The first type corporate programmes - was initiated and “ordered" by Severstal headquarters, which also covered programme costs (either all or partial costs). These programmes compounded a certain SCU "curriculum" and were provided annually with certain adjustments. Thus, during the regarded period, SCU elaborated on and launched some new corporate programmes, such as "Talent Pool" in 2003, "Top 100" in 2004, and "Perspektiva" in 2005 - to be added to the MBA programme that had been running since 2000. These programmes were different in terms of the target group, length, purpose, and training tools employed. The second type - tailor-made programmes - were ordered and paid for by particular enterprises of the Severstal Group. These programmes were much more customised and individual and were meant to satisfy the knowledge needs of particular enterprises or divisions. According to the SCU managers, these tailor-made programmes constituted one of the most in-demand services in the SCU portfolio. The realisation of such programmes required close cooperation between the SCU and the client enterprise at all stages of programme development. In addition to corporate and tailor-made training programmes, the SCU facilitated a project at the HR school that was meant to develop HR staff members. The HR schools were organised separately for the HR employees within the Resources and Metalware divisions.

Another service provided by SCU for the Group enterprises was the launch of the
Severstal System of Electronic and Distance Learning (SEDL), also known as the corporate e-learning system. The system was regarded as a tool to satisfy the divergent learning needs of the highly diversified enterprises within the Severstal Group. The major reason for establishing the SEDL was to enable convenient and easy mass learning for Severstal employees in various professional areas, regardless of their physical location. The e-learning system was a selftraining resource containing a comprehensive library of electronic courses in Russian and English that covered a range of subjects in different fields such as leadership and management, finance and marketing, safety and fundamental metallurgy, etc.

In order to satisfy the divergent knowledge needs of the Severstal enterprises, SCU launched and operated knowledge bases. Knowledge bases were meant for the accumulation and storage of relevant information, best practices, and formalised knowledge that could be easily accessed and retrieved by Severstal employees. The main role of the knowledge bases was thus seen as preservation of accumulated competence and experience in order to eliminate unnecessary repetitions of the same procedures [The Synergy, 2006, p. 16].

Several types of knowledge bases were developed by SCU. One of them was referred to as the so-called Corporate Knowledge Base (CKB). CKB was the largest storage resource and contained various types of professional information in different fields of competency. These included books, articles, lists of e-courses, documents, corporate policies, and other publications, such as presentations and similar material from corporate conferences and seminars. Besides CKB, a Corporate Base of Experts (CBE) was developed, which contained all the information about the experts employed by Severstal. The purpose of this base was to make experts visible in the corporation and to provide Severstal employees with the opportunity to contact a competent person to request a consulta-

PЖM 15 (1): 51-68 (2017) 
tion. Another type of knowledge base was the local knowledge bases (LKBs). These bases were expanded in certain subject areas by the orders of particular enterprises. Such bases were "customised" and were used locally. LKBs were meant to be a storage for formalised enterprise-specific internal competence, knowledge, and valuable experience, which could be accessed and retrieved by its employees.

At this stage, SCU continued provision of services related to corporate studies and internal consulting, the scope of which increased due to the increased demand for this type of service expressed by enterprises and divisions.

Finally, during the regarded stage, SCU started performing some services in the field of human resources. At that, time the Severstal Group did not possess a unified Directorate for HR - as argued, due to a high degree of diversity among the enterprises of the Group [The Synergy, 2004]. At the same time, some enterprises experienced a high level of human capital drain and deficits in the labour force. Local HR services could not handle the situation and provide the enterprises with the required work force. In order to assist enterprises in this matter, SCU established the Centre for Human Resources; one of its main tasks was to recruit staff for the Severstal enterprises. The centre was created as an alternative to external recruiting agencies, and it operated on site in the Severstal enterprises. It was assumed that a corporate recruiting service possessed a better knowledge of work specifics, qualification requirements, and harmful factors in the workplaces of Severstal enterprises than external recruits did. Simultaneously, being a full-fledged recruiting agency, the centre was argued to provide a convenient service for job seekers. The centre offered vacant positions at Severstal to those who came in search of a job. Thus, the recruiting task performed by the Centre for HR was seen as potentially beneficial both for the HR units of the Severstal en- terprises and the local community [The Synergy, 2006].

In summary, during the regarded period, the SCU's knowledge-related efforts and activities were concentrated on satisfying the divergent knowledge needs of Severstal enterprises. While acting as a "service centre", the SCU provided a wide spectrum of tailor-made services to the business units of the Severstal Group.

\section{Integration tool}

The next set of the SCU knowledge-related tasks appeared when:

\begin{abstract}
Severstal management expressed a wish and took certain steps to create a unified, integrated, centralized company with a strong corporate culture, and unified practices... Such a concept was adopted, and this caused the need to change SCU's strategies and practices. (SCU Director)
\end{abstract}

The company made several crucial steps towards more transparency and publicity, such as placing its IPO on the London Stock Exchange and introducing a new governance structure. These changes had the following impact on SCU:

SCU has got a new set of tasks - the theme of social corporate responsibility, corporate management, organization of internal business processes, etc. And there was a new coil in the development of the company, which SCU development depended on. (SCU Director)

To illustrate SCU promoting corporate social responsibility (CSR) issues at Severstal, we can refer to a project on vocational guidance. This project was initiated by Severstal top management and run by the SCU's Centre for Human Resources. In particular, the Centre created a leaflet, a video, and a page on the SCU website to provide information about the metallurgy and steelmaking business in general and about working professions in the metallurgical industry more specifically. The videos narrated 
the life and profession of young concrete specialists working at Severstal. Free copies of leaflets and videos were disseminated in schools to be shown to pupils - as a part of a vocational counselling programme. The purpose of this vocational counselling was to motivate young people, mostly of school graduation age, to choose an education and profession in the steel-making business and to promote Severstal as an attractive potential employer. Other examples of CSR activities performed by SCU included initiating contests about metallurgical issues and involving youth in local and international competitions related to the steelmaking industry.

The above-mentioned themes of CSR, corporate management, etc. became the main subjects of discussion in the corporate magazine, The Synergy. A new column was introduced in the journal dedicated to those social and charity projects in which Severstal was involved. In particular, Severstal was reported to support cultural and historical heritage initiatives (e.g., museums), modern culture, children, and sports activities [The Synergy, 2006].

Since 2006, Severstal management concentrated on their core business field - mining and steel. Non-profile businesses were either sold or detached. The consolidated company JSC Severstal ("OAO Severstal”) was formed: a parent company owning the whole mining and smelting chain. In comparison with the previous periods, the company became much more centralised, drawing changes for the SCU operation. Previously SCU had provided a service in a very decentralised and mixed "market", i. e., for a very broad range of businesses. However, after the structural and strategic changes at Severstal, SCU tasks became more centralised and aligned to the needs and demands of headquarters. The SCU Director explained it further:

We must assist the company to integrate, and therefore, the role of the centralized common programmes is increasing. Before we took into much consideration the needs of the enterprises, which were very different, and that's why our projects were very decentralized. In fact, this demands us to create a new system of management development and talent management. And the second change is that during the last years the company became global. Now the company embraces not only Russians, but also American, French, Italian, English, Ukrainian people... The divisions have changed and become mature... each of them has obtained its own experience. But now the task - "gathering strengths and stones". We have to gather it all together again; we need to assist in building a unified company. Thus, we have to assist the company in developing centralized approaches. And firstly, develop a unified strong corporate culture.

Thus, the new role of SCU implied assisting the parent company in the internationalisation and integration of the business, which in its turn imposed new requirements for the HR training and development performed by SCU:

The company has grown very much; it has become international. Almost half of the output would be produced abroad. Hence, there is a great need for dealers at a high level. Before we provided a wide range of services and developed programmes for the categories from junior management to top management. But now we concentrate on the upper leadership level, company managers, and developing their successors - people with high potential. Simultaneously we are developing an international cross-cultural component of our programmes. For instance, we have launched a new programme called "Global Leadership". Part of the company's strategy is turning into the global company, as well as economically justified mergers and acquisitions. Therefore, we need people who are able to manage big, serious, international, and cross-cultural projects. (SCU Director) 
Thus, in order to promote internationalisation in training, SCU introduced new programs taught in English for the development of managers capable of working internationally. At the same time, SCU enriched the library of e-courses with courses provided in English, which became available for employees of the international segment.

Besides these steps, aimed at supporting the internationalisation and integration strategy of the company, SCU facilitated international seminars with the participation of Severstal specialists from Russian and foreign enterprises. These seminars were related to such business areas as HR management, procurement, marketing and sales, production, investment management (e.g., [The Synergy, 2006]). SCU also organised international conferences for the directors and managers of the Severstal enterprises, which have been held in English since 2006 . The internationalisation trend was also reflected in the corporate magazine, which introduced an English digest version in 2008.

In summary, during this period, the SCU's knowledge-related tasks were focused on assisting the parent company to integrate its business and operate in an international setting. In light of the vertical integration and centralisation tendency, the role of headquarters as the SCU's main client increased. While continuing to act as the "service centre" for the Severstal enterprises, SCU received a new set of tasks to satisfy the specific knowledge needs of headquarters. In particular, SCU identified the need for new corporate training initiatives that would reflect internationalisation and integration tendencies and became more actively involved in CSR projects.

\section{Understanding coordination of knowledge flows: three coordination functions of the SCU}

In the previous section, we described how SCU functioned in the context of the corporate network and how it responded to the emergent knowledge needs of the parent company driven by changing strategic aspirations. The study considered three particular periods of Severstal's corporate development. The findings suggest that during different stages of company operations, the corporate university performed its knowledge coordination function differently. Table 2 summarises the previous section and presents empirical findings in light of the discussion provided in the theoretical section.

While highlighting three stages of corporate development, the table illustrates how the SCU's operation as "knowledge coordinator" differed in terms of the desired state of "order" to be achieved, timing (reflecting the characteristics of the particular stage of organisational development), major knowledge-related efforts, and the type of knowledge transferred. Based on these differences the knowledge coordination function performed by SCU can be perceived as either in terms of "knowledge-harmonising", "knowledge-disseminating" or "knowledge-centralisation" hub. These are explained below in more detail.

At the first stage, the newly formed Severstal Company consisted of very divergent enterprises operating in various branches of industry. Many of the newly acquired enterprises were in a poor state, and the workforce moods were characterised by a high degree of discontent, mostly as a result of low pay. In this situation, the desired state of "order" was seen in harmonisation of business approaches - that is, to achieve a certain degree of commonality and normalisation of business practices among the dissimilar enterprises of the Group. The scope of the SCU's knowledge-related efforts was related to identifying a particular type of organisational knowledge - best management practices - and transferring these best practices from the successful enterprises, such as key business units, to the distressed units.

Previous research has highlighted that transfer of best practices from one business 
Table 2

Understanding coordination of knowledge flows in the Severstal context

\begin{tabular}{|c|c|c|c|}
\hline \multirow{2}{*}{$\begin{array}{l}\text { Coordination } \\
\text { element }\end{array}$} & \multicolumn{3}{|c|}{ Development stage } \\
\hline & $\begin{array}{c}\text { Stage 1 } \\
(2001-2002)\end{array}$ & $\begin{array}{c}\text { Stage } 2 \\
(2003-2005)\end{array}$ & $\begin{array}{c}\text { Stage 3 } \\
(2006-2008)\end{array}$ \\
\hline Timing & $\begin{array}{l}\text { Multiple branches, } \\
\text { diversity of enterprises, } \\
\text { distressed assets, dis- } \\
\text { contented staff }\end{array}$ & $\begin{array}{l}\text { Acquisitions and growth, } \\
\text { decentralisation, high de- } \\
\text { gree of divisional autonomy }\end{array}$ & $\begin{array}{l}\text { Increasing degree of verti- } \\
\text { cal integration, unification } \\
\text { of practices, and structural } \\
\text { transparency }\end{array}$ \\
\hline $\begin{array}{l}\text { "Order" to be } \\
\text { achieved }\end{array}$ & $\begin{array}{l}\text { Commonality and har- } \\
\text { monisation of business } \\
\text { practices }\end{array}$ & $\begin{array}{l}\text { Meet diverse knowledge-re- } \\
\text { lated demands of dissimilar } \\
\text { enterprises }\end{array}$ & $\begin{array}{l}\text { Meet the needs of headquar- } \\
\text { ters in performing centralisa- } \\
\text { tion and internationalisation }\end{array}$ \\
\hline $\begin{array}{l}\text { Major knowledge- } \\
\text { related efforts }\end{array}$ & $\begin{array}{l}\text { Identify and transfer } \\
\text { "best practices" and } \\
\text { ensure their effect }\end{array}$ & $\begin{array}{l}\text { Identify the needs of the } \\
\text { enterprises and design } \\
\text { tailor-made products/ser- } \\
\text { vices }\end{array}$ & $\begin{array}{l}\text { Identify needs of headquar- } \\
\text { ters in training programmes, } \\
\text { CSR issues, and corporate } \\
\text { culture, and provide central- } \\
\text { ised solutions }\end{array}$ \\
\hline $\begin{array}{l}\text { Type of know- } \\
\text { ledge }\end{array}$ & $\begin{array}{l}\text { Corporate standards. } \\
\text { Consulting knowledge } \\
\text { "Signs of environment" } \\
\text { (corporate studies) }\end{array}$ & $\begin{array}{l}\text { E-courses. } \\
\text { Knowledge bases. } \\
\text { Tailor-made and corporate } \\
\text { training programs. } \\
\text { "Recruiting" agency }\end{array}$ & $\begin{array}{l}\text { International corporate train- } \\
\text { ing programmes. } \\
\text { Corporate culture promoted } \\
\text { through tailor-made pro- } \\
\text { grammes. } \\
\text { CSR theme }\end{array}$ \\
\hline SCU function & $\begin{array}{l}\text { SCU as "knowledge har- } \\
\text { monising" hub }\end{array}$ & $\begin{array}{l}\text { SCU as "knowledge dis- } \\
\text { seminating" hub }\end{array}$ & $\begin{array}{l}\text { SCU as "knowledge centrali- } \\
\text { sation" hub }\end{array}$ \\
\hline
\end{tabular}

unit to another is "extremely difficult" due to motivation-related barriers, lack of absorptive capacity, and casual ambiguity [Szulanski,1996] referring to [Goold, Campbell, Alexander, 1994]. In the case of Severstal, SCU acted as a "bridge" to transfer best practices from one unit to another (see fig. 1). In this way, the SCU's function could be defined as a being a "knowledge-harmonising" hub, facilitating flows of organisational knowledge in the form of "best practices" from enterprise A to enterprise B.

The second regarded period of Severstal's development was characterised by active acquisitions of profiled and non-profiled assets and hence, rapid grow. At that stage, the company structure revealed a high degree of decentralisation and business autonomy. Strategic focus was set on facilitating further growth - in terms of mar- ket share, production volume, and revenues. In this light, securing cost optimisation and production efficiency at various enterprises of the Group was seen as an important objective. The decentralised business model permitted business units to make relatively independent decisions concerning their knowledge needs and hence the services that they requested from SCU. The desired state of order in relation to knowledge-focused activity at this stage was meeting diverse and specific knowledgerelated demands of various Severstal enterprises. In this sense, SCU was attributed with the role of a "service centre". In the words of the SCU Director, SCU acted as a "problem-solving firm" and was involved in bilateral client-executor relations, as shown in fig. 2. The knowledgerelated efforts of the SCU "service centre" were concentrated on identifying the na- 


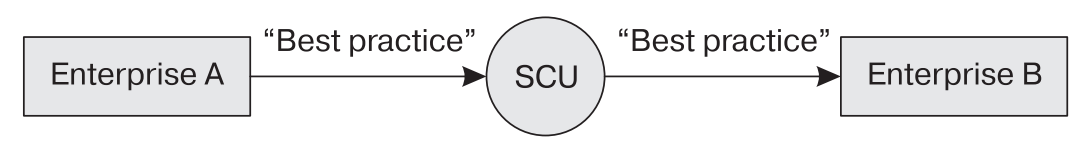

Fig. 1. SCU as a "knowledge-harmonising" hub coordinating knowledge flows in terms of "best practices"

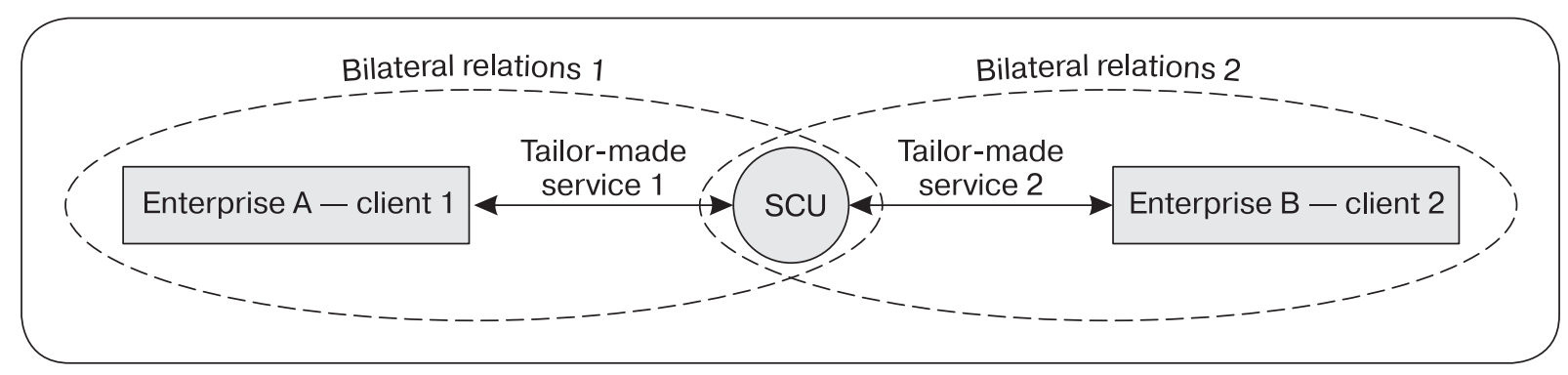

Fig. 2. SCU as a "knowledge-disseminating" hub coordinating knowledge flows by way of tailor-made services

scent needs of the business units and designing and implementing tailor-made solutions. The types of knowledge transferred were driven by the specific needs of the enterprises. In this situation, the SCU's function can be define as a being a "knowledge-disseminating" hub that provided enterprises with customised services through e-learning, knowledge bases, various training programs, and recruiting services - in addition to consultancy projects and corporate studies.

The types of knowledge transferred via different SCU initiatives were grouped into categories and represented a "portfolio" of SCU services from which business units could choose what was of special interest to them. If a ready-made solution did not satisfy their requirements, they could order a customised solution to suit their individual knowledge needs. Serving to satisfy the different knowledge needs of the enterprises was thus the essence of the SCU's "knowledge-disseminating" function.

At this stage of operations, the scope and focus of the SCU activities was essentially broadened in comparison with the previous stage. The complexity of the SCU's knowledge coordination function essentially increased as the scope of the SCU's tasks became more sophisticated and included HR training and development, change implementation, and recruitment and information supply.

At the third stage, Severstal - already become an international company by that time - experienced the need to integrate and re-organise its assets to make the corporate structure more transparent and attractive for foreign investors. The need to comply with international standards and requirements posed new challenges for Severstal, and hence new knowledge needs evolved. The desired state of "order" to be achieved was related to skilful management of the international company, a strong corporate culture, and unified goals and values as well as clear-cut CSR policies and practices. As a result of the vertical integration and internationalisation focus adopted by Severstal, the SCU's knowledge-related efforts were essentially concentrated on identifying specific knowledge needs and providing centralised solutions to headquarters. The major types of knowledge to be transferred at this third stage were related to 


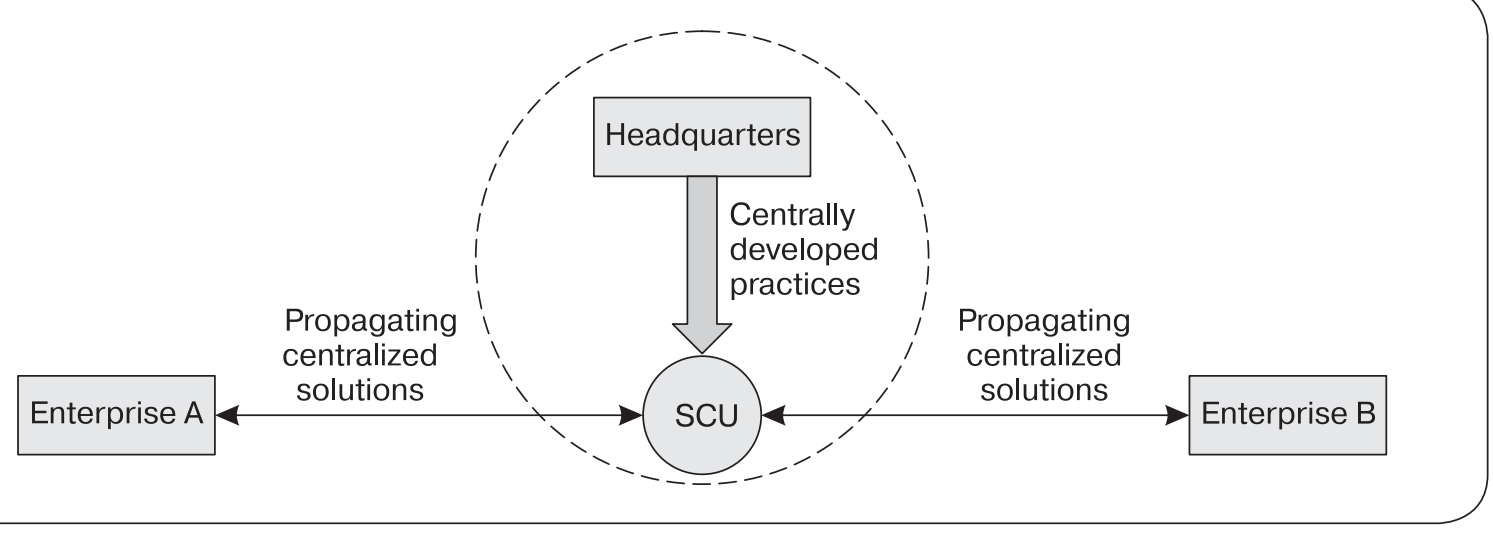

Fig. 3. SCU as a "knowledge-centralisation" hub coordinating knowledge flows in terms of centrally developed practices for headquarters

training, CSR issues, and corporate culture. The knowledge coordination function of SCU during this period can be defined as being that of a "knowledge-centralisation" hub that assists headquarters in implementing its integration and internationalisation strategy, developing appropriate practices and solutions, and then propagating them throughout the enterprises of the Group, as depicted in fig. 3 .

The SCU's knowledge coordination function at this stage was characterised by the highest intensity in terms of the knowledge flows coordinated by SCU - also due to SCU continuing to perform their activities from the first and second periods. Thus, coordination of knowledge flows at this stage became even more sophisticated due to the increasing complexity of the directionality of knowledge flows, the types of knowledge to be transferred, and the combined knowledge activities of all three stages - whereas the main emphasis was set on knowledgecentralisation efforts.

\section{Epilogue. The "fall" of SCU and its successor}

The first signs of the dramatic for SCU changes appeared at the end of 2008, when Company CEO warned about the coming cutbacks due to the 2008 world financial crises. Layoffs, restructuring, and cost reductions - that would also affect the SCU programmes - were some of the crises' negative consequences [The Synergy, 2008, November, p.9]. The Company was seriously hit by the crises, and concentrated its efforts on cost-saving and regaining profitability. In April 2010 SCU was officially closed down.

Upon the closure of SCU, some of its functions were delegated to a new unit called the Directorate of HR Recruitment and Development (hereafter referred to as the "Directorate"). The Directorate was organized as a unit (department) within Severstal headquarters. Like in the case of SCU, the tasks of the new unit were driven by the strategic aspirations of Severstal company that continued pursuing its course towards centralization and integration. The Head of the newly established Directorate perceived the change that had occurred as a "coherence between the required structure and the tasks given by the Company":

The structure always corresponds to the particular task, and should be renewed when the task has been changed. If the task changes - the structure can't be left the same. Not every structure is effective for any task. That's why this task requires this type of structure. 
In this way, centralization of Company's structure and cost-saving efforts resulted in SCU closure and establishment of the Direcorate. The Directorate's major role was to serve as an "expertise centre" in the areas of human resources recruitment, development and strategizing. The new unit interacted with the HR departments of the Severstal enterprises, and provided consultation in HR processes and methodology. Thus, for instance, the Directorate was in charge of "talent management" in order to avoid "over-training of staff". At the same time, the Directorate abandoned some of the SCU functions. For example, consultancy function was dismissed.

In comparison with SCU, which served as a "service centre" for the Severstal enterprises, the position of the Directorate revealed a strong centralization trend, meanwhile the focus became sharper. The general impression is that the scope of knowledge flows coordinated by the Directorate had been narrowed down and focused on issues of $\mathrm{HR}$ administration.

\section{Conclusion}

This paper proposes and develops a new conceptual understanding of a corporate university - as a coordinator of organisational knowledge flows. Through the study of Severstal CU, we have demonstrated how at different periods of corporate development, the CU performed three different knowledge-coordinating functions: "knowledgeharmonising", "knowledge-disseminating", and "knowledge-centralising". These functions were different in terms of the "order" to be achieved, knowledge-related efforts, and the type of organisational knowledge to be transferred.

By explaining the connection between the evolving knowledge needs of the parent company and the CU's knowledge coordination functions, the study provided a deeper understanding about how the CU actually supports the business objectives of the parent company [Abel, Li, 2012] and acts to assist its strategic development [Antonelli, Cappiello, Pedrini, 2013].

As opposed to the majority of studies using the traditional life cycle perspective to explain the development of a corporate university [Abel, Li, 2012], this study provides an explanation of CU's development in terms of the teleological nature of change (see [Van De Ven, Poole, 1995]) ${ }^{2}$. From this point of view, the phases of CU development are triggered by the changes in the CU's knowledge coordination functions, reflecting the evolving knowledge needs of the parent company.

The results of this study may be of interest to a broad number of practitioners involved in corporate knowledge management initiatives. The experience of Severstal CU provides important insight about facilitating organisational learning and coordinating flows organisational knowledge between business units. Further, the study highlighted the importance of understanding the corporate university as a dynamic concept that links its knowledge-related practices to evolving corporate strategy and changeable knowledge needs.

It is difficult to generalise the findings concerning CU practices from a single case study. Therefore, in order to obtain a better understanding of the functions and practices related to the coordination of knowledge flows, further research is needed. Future studies should embrace a broader population of corporate universities in different industries and investigate, for example, how the financial performance of the parent

\footnotetext{
${ }^{2}$ We recognize the value of terminology proposed by [Van de Ven, Poole, 1995] in their typology of the process theories of change. The life-cycle mode of change is prescribed, and the change process is one in which the entity progresses through a necessary, programmed and known in advance sequence of stages. Teleological change is constructive and focused on reaching an envisioned goal, and occurs through an emergent and socially defined process of iterative implementation and modification moving towards that goal.
} 
company influences the knowledge-coordination functions of the corporate university. This matter seems to be actual, in particular with the reference to SCU's closure due to the world financial crises. Further, it could be interesting to address the role of organisational structure for coordination of knowledge flows given that different knowledge-related task require different types of structure.

\section{REFERENCES}

Abel A.L., Li J. 2012. Exploring the corporate university phenomenon: Development and implementation of a comprehensive survey. Human Resource Development Quarterly 23 (1): 103-128.

Alagaraja M., Li J. 2014. Utilizing institutional perspectives to investigate the emergence, rise, and (relative) decline of corporate universities. Human Resource Development International 18 (1): 4-23.

Allen M. 2010. Corporate universities 2010: Globalization and greater sophistication. The Journal of International Management Studies 5 (1): 48-53.

Ambos T.C., Ambos B. 2009. The impact of distance on knowledge transfer effectiveness in multinational corporations. Journal of International Management 15 (1): 1-14.

Antonelli G., Cappiello G., Pedrini G. 2013. The Corporate University in the European utility industries. Utilities Policy 25: 33-41.

Ardichvili A., Zavyalova E. 2015. Human Resource Development in the Russian Federation. Routledge: N.Y.

Barney J. 1991. Firm resources and sustained competitive advantage. Journal of Management 17 (1): 99-120.

da Silva F. S.C., Agustí-Cullel J. 2003. Issues on knowledge coordination. Knowledge and Process Management 10 (1): 37-59.

Dixon S.E.A., Day M., Brewster C. 2014. Changing HRM systems in two Russian oil companies: Western hegemony or Russian spetsifika? The International Journal of
Finally, an improved understanding of the corporate university as the coordinator of knowledge flows may be obtained by implementing a comparative study of corporate universities in different national and cultural settings. It would be interesting to investigate more closely how differences in management styles and culture (e.g., [Fey, Denison, 2003; Fey, Shekshnia, 2011]) produce variations.

Human Resource Management 25: 1-23.

Fey C.F., Denison D.R. 2003. Organizational culture and effectiveness: Can American theory be applied in Russia? Organization Science 14 (6): 686-706.

Fey C.F., Shekshnia S. 2011. The key commandments for doing business in Russia. Organizational Dynamics 40 (1): 57-66.

Garud R. 1997. On the distinction between know-how, know-why, and know-what. $A d$ vances in Strategic Management 14: 81101.

Ghoshal S., Korine H., Szulanski G. 1994. Interunit communication in multinational corporations. Management Science 40 (1): 96-110.

Goold M., Campbell A., Alexander M. 1994. Corporate-level Strategy: Creating Value in the Multibusiness Company. Wiley: N.Y.

Gorshkov M.K., Kliucharev G.A. 2013. The current state and prospects of corporate education. Russian Education and Society 55 (9): $23-46$.

Gupta A. K., Govindarajan V. 1991. Knowledge flows and the structure of control within multinational corporations. Academy of $\mathrm{Ma}$ nagement Review 16 (4): 768-792.

Holland P., Pyman A. 2006. Corporate universities: A catalyst for strategic human resource development? Journal of European Industrial Training 30 (1): 19-31.

Holm U., Sharma D. D. 2006. Subsidiary marketing knowledge and strategic development of the multinational corporation. 
Journal of International Management 12 (1): 47-66.

Hong J.F. L., Easterby-Smith M., Snell R.S. 2006. Transferring organizational learning systems to Japanese subsidiaries in China. Journal of Management Studies 43 (5): 1027-1058.

Konovalenko Slettli V., Grønhaug K. 2016. On the two perspectives on coordination of knowledge flows: Knowledge-enabling and control. Beta: Scandianvian Journal of Business Research 30 (2): 158-173.

Kostova T., Roth K. 2002. Adoption of an organizational practice by subsidiaries of multinational corporations: Institutional and relational effects. Academy of Management Journal 45 (1): 215-233.

Kotlarsky J., van Fenema P.C., Willcocks L.P. 2008. Developing a knowledge-based perspective on coordination: The case of global software projects. Information \& Management 45 (2): 96-108.

Latukha M. 2010. Ilim Pulp, blending former Russian state enterprises, creates a corporate university to change culture, become an industry leader. Global Business and Organizational Excellence 29 (5): 40-51.

Latukha M. 2015. Talent management in Russian companies: Domestic challenges and international experience. The International Journal of Human Resource Management 26 (8): 1051-1075.

Malik K. 2004. Coordination of technological knowledge flows in firms. Journal of Knowledge Management 8 (2): 64-72.

Michailova S., Mustaffa Z. 2012. Subsidiary knowledge flows in multinational corporations: Research accomplishments, gaps, and opportunities. Journal of World Business 47 (3): 383-396.

Nielsen B. B., Michailova S. 2007. Knowledge management systems in multinational corporations: Typology and transitional dynam- ics. Long Range Planning 40 (3): 314-340.

Rhéaume L., Gardoni M. 2015. The challenges facing corporate universities in dealing with open innovation. Journal of Workplace Learning 27 (4): 315-328.

Rhéaume L., Gardoni M. 2016. Strategy-making for innovation management and the development of corporate universities. International Journal on Interactive Design and Manufacturing 10 (1): 73-84.

Schulz M. 2001. The uncertain relevance of newness: Organizational learning and knowledge flows. Academy of Management Journal 44 (4): 661-681.

Schulz M. 2003. Pathways of relevance: Exploring inflows of knowledge into subunits of multinational corporations. Organization Science 14 (4): 440-459.

Sparkes J.R., Miyake M. 2000. Knowledge transfer and human resource development practices: Japanese firms in Brazil and Mexico. International Business Review 9 (5): 599-612.

The Synergy. 2004-2008. Corporate magazine. Cherepovets: Severstal Corporate University.

Szulanski G. 1996. Exploring internal stickiness: Impediments to the transfer of best practice within the firm. Strategic Management Journal 17 (S2): 27-43.

Teece D. J. 2000. Managing Intellectual Capital: Organizational, Strategic, and Policy Dimensions. Oxford University Press: Oxford, UK.

Tsai W. 2002. Social structure of "coopetition" within a multiunit organization: Coordination, competition, and intraorganizational knowledge sharing. Organization Science 13 (2): 179-190.

Van De Ven A. H., Poole M.S. 1995. Explaining development and change in organizations. Academy of Management Review 20 (3): $510-540$.

DOI: $10.21638 / 11701 /$ spbu18.2017.103

Initial Submission: December 16, 2016 Final Version Accepted: March 27, 2017 


\section{Координация потоков организационного знания: роль корпоративного университета}

\section{В. Коноваленко Слеттли}

Университет прикладных наук Внутренней Норвегии, Норвегия

\section{К. Грюнаг \\ Норвежская школа эконолики, Норвегия}

Цель статьи - улучшить понимание феномена корпоративного университета через обращение к той роли, которую играет корпоративный университет в координации потока организационного знания. В работе представлен лонгитюдный кейс корпоративного университета «Северстали» . Мы демонстрируем, как корпоративный университет содействует динамическому управлению знаниями в компании, выступая в качестве координатора потоков знаний. Исследование предлагает свидетельства того, как корпоративный университет, выполняя три роли в координации знаний, несет корпоративную функцию поддержки развивающегося бизнеса в разные периоды организационного развития. Полученные результаты позволяют выделить следующие роли корпоративного университета, связанные с координацией потоков знаний: гармонизация знаний, распространение знаний и централизация знаний. Результатом анализа является динамическая концепция корпоративного университета, стадии развития которого объясняются скорее с телеологической точки зрения, нежели с точки зрения жизненного цикла. Иными словами, развитие корпоративного университета управляется его изменяющимися целью и задачами. Они, в свою очередь, формулируются и пересматриваются в соответствии с меняющимися потребностями материнской компании в сфере управления знаниями.

Ключевые слова: корпоративный университет, потоки знаний, координация, стратегическое развитие, кейс-метод.

JEL: D83, M12, I21.

DOI: $10.21638 / 11701 /$ spbu18.2017.103

Статья поступила в редакиию 16 декабря 2016 г. Принята к публикации 27 мларта 2017 г. 